\title{
Transformation of infrastructure to ensure economic security of the enterprise
}

\author{
Roman S. Marchenko \\ Graduate School of Business and \\ Management \\ Peter the Great St.Petersburg \\ Polytechnic University \\ St. Petersburg, Russia \\ marchenko_rs@spbstu.ru
}

\author{
Mark P. Vlasov \\ Economic security department \\ St. Petersburg State University of \\ Architecture and Civil Engineering \\ St. Petersburg, Russia \\ markvlasov@mail.ru
}

\begin{abstract}
The purpose of the article is to determine the economic security of the enterprise, which is based on the identification of parties interested in its successful activities. The necessary and sufficient conditions for ensuring the economic security of the enterprise are offered. At such approach threats to economic security are considered as negative consequences of earlier accepted administrative decisions. In the given article the attempt to define economic safety of the enterprise from the point of view of interests of the owner, without ignoring thus all parties interested in its activity is undertaken.
\end{abstract}

To achieve the set goal the analysis of the mechanism of influence on efficiency of activity of the enterprise which characterizes the degree of its economic security is carried out. Problems of ensuring economic security of enterprises of different branches of economy are indicated. Author's definitions are given, principles are formulated and approaches to solving the problem of ensuring economic security of enterprises are defined. The ways of improvement of activity on maintenance of economic safety of the enterprise are specified and methodical recommendations are given. Proceeding from the interests of owners, the market must synchronize the actions of enterprisessellers and buyers, establishing a balance between the volume of output and price. From this point of view, the economic security of the enterprise consists in the guaranteed receipt of income, satisfying, first of all, the owner. Sufficient attention is paid to the role of the state, interested in the creation of enterprises oriented to the export of their products. Different attitude of the state to the enterprises, the production of which is intended for internal and external markets, is revealed.

Each enterprise acts in the market not only as the seller, but also as the buyer. Therefore, its existence, i.e. its safety, depends on other sellers as well. Therefore, by acting both as a seller and a buyer, the enterprise can ensure its security through the efficient use of the property at its disposal. Therefore, the preservation and growth of property is the main task of ensuring the economic security of the enterprise.

Keywords- enterprise economic security, business operation, business process, logistics, value chain, threats.

\section{INTRODUCTION}

In order for an enterprise to function effectively, it must have the infrastructure to adapt to an ever-changing environment that threatens its existence. Here, the management of information, material, financial and energy flows is a central part of the enterprise's activities, as the volume of its own work in the enterprise's products rarely exceeds $50 \%$.

In addition to material, instrumental and energy resources, economic activity requires information that determines the opportunities for obtaining and using resources [17]. The possibility of "digitalization" of the economy is determined by the possibilities of presenting information, its properties, methods of evaluation and communication to the consumer. And the security of the digital economy is based on the ways of processing, transmission and use of information. "Business, government and civil society leaders ... are making every effort to reform their organizations to fully understand the benefits of digital opportunities. We stand at the very beginning of the fourth industrial revolution, and to perceive its full significance requires the presence of fundamentally new economic and organizational structures" [10]. Moreover, information flows can play both an independent and servicing role, as information flows must necessarily accompany material, financial and energy flows. This provision applies to the internal and external environment of the enterprise. From the point of view of the functioning of the enterprise it is advisable to identify its interaction with the external environment and consider it as economic operations, which is characterized by cost indicators, and the activity in the internal environment to be considered from the point of view of time spent by the personnel (labor intensity). The activity of the personnel seems to be a set of business processes. The first difference between a business operation and a business process is that there are two counter-flows in the business operation. One is material (or informational) and the other is financial. For example, delivery of products to the consumer (material flow) on the one hand, and payment by the consumer for delivered products (financial flow) - on the other hand.

The second difference between a business operation and a business process is the planning of their implementation. If planning of performance of business process is a prerogative of planned services of the enterprise planning of performance of economic operation should be carried out in the terms defined by the contract with the partner or the buyer that demands the coordinated actions. 
Economic operation represents the logistical process in the external environment of the enterprise, causing changes in structure, placing and sources of formation of the basic and circulating means. In accounting, an economic operation is any fixed economic action of a subject related to the movement of funds and valuables. All economic operations can be conditionally divided into four groups depending on the results of their reflection in the balance sheet (Table 1).

Accounting records reflect only completed business operations. Being the primary unit of accounting observation, an economic operation records the change or termination of economic and legal relations, which leads to a change in the assets of the organization. Economic operation is aimed at interaction of the enterprise with partners, clients (buyers), the owner and the state. Thus, an economic operation, being a logistics operation, reflects the activities of logistics and management structures, which establish, above all, the necessary information contacts with buyers (contracting for the supply of products of the enterprise and its sale) and partners (contracting for the supply of necessary components for the production of products) [2]. Directly all contracts are concluded by the head of the enterprise, which are fixed in the planned services of the enterprise. Accounting, responsible for the integrity of property, is responsible for the correctness of calculations of the enterprise with customers, partners, owner and the state. Performance of concluded contracts is accompanied by material or energy flows with appropriate information support. Therefore, business operations ensure the activity of the enterprise through interaction with the external environment, thus ensuring the economic security of the enterprise.

The internal environment of an enterprise is represented by business processes that are classified as:

- main (directly involved in the creation of the enterprise's products);

- Logistics (ensuring the creation of products);

- management (organizing interaction between the owners of the main and logistic business processes).

If economic operations have a cost estimation of results of the activity the business process is characterized by labour input of carried out works (expenses of working hours).

The main business processes are the operations of the value chain of products produced by the enterprise [8].

Analyzing the value chain, it should be noted that its composition should include logistics operations that ensure the execution of basic operations, and a mechanism to ensure consistency of actions of participants in the value chain [5].

TABLE I. CLASSIFICATION OF BUSINESS TRANSACTIONS

\begin{tabular}{|l|l|l|}
\hline $\begin{array}{l}\text { Groups } \\
\text { x/operations }\end{array}$ & $\begin{array}{l}\text { Content of business } \\
\text { operations }\end{array}$ & $\begin{array}{l}\text { Balance Sheet } \\
\text { Reflection }\end{array}$ \\
\hline 1 & $\begin{array}{l}\text { The use of valuables } \\
\text { in the production } \\
\text { process, for the }\end{array}$ & $\begin{array}{l}\text { They are reflected } \\
\text { only in the balance } \\
\text { sheet asset by }\end{array}$ \\
& $\begin{array}{l}\text { production of } \\
\text { increasing one of its }\end{array}$ \\
& shished goods, their & items and \\
& of achent, repayment \\
& receivable, accounts & $\begin{array}{l}\text { decrease by the same } \\
\text { amount of another }\end{array}$ \\
\hline
\end{tabular}

\begin{tabular}{|c|c|c|}
\hline & $\begin{array}{l}\text { withdrawal of cash } \\
\text { from the current } \\
\text { account to be } \\
\text { recorded in cash }\end{array}$ & $\begin{array}{l}\text { one. The result of the } \\
\text { balance sheet does } \\
\text { not change, because } \\
\text { in this case, only the } \\
\text { composition and } \\
\text { allocation of funds } \\
\text { of the organization } \\
\text { are changed }\end{array}$ \\
\hline 2 & $\begin{array}{l}\text { Withholding taxes } \\
\text { on income from staff } \\
\text { salaries, distribution } \\
\text { of profits, repayment } \\
\text { of debts to suppliers } \\
\text { at the expense of the } \\
\text { received loan. } \\
\text { Economic operations } \\
\text { cause changes in the } \\
\text { balance sheet } \\
\text { liability, as the } \\
\text { sources of economic } \\
\text { funds change }\end{array}$ & $\begin{array}{l}\text { One balance sheet } \\
\text { item increases and } \\
\text { the other decreases } \\
\text { by the amount of the } \\
\text { related payments }\end{array}$ \\
\hline 3 & $\begin{array}{l}\text { Accrual of funds on } \\
\text { account of the } \\
\text { contributions of } \\
\text { founders, } \\
\text { depreciation of fixed } \\
\text { assets, depreciation } \\
\text { of low-value and } \\
\text { wearing items, } \\
\text { intangible assets, as } \\
\text { well as accrual of } \\
\text { wages at the expense } \\
\text { of the cost of } \\
\text { products (works, } \\
\text { services), advance } \\
\text { payments of } \\
\text { customers, obtaining } \\
\text { loans, etc. }\end{array}$ & $\begin{array}{l}\text { Reflected both in the } \\
\text { asset and liability of } \\
\text { the balance sheet by } \\
\text { increasing its items } \\
\text { and, accordingly, } \\
\text { increasing the } \\
\text { balance sheet total } \\
\text { by the amount of } \\
\text { economic operation } \\
\text { on the asset and } \\
\text { liability }\end{array}$ \\
\hline 4 & $\begin{array}{l}\text { Repayment of any } \\
\text { types of accounts } \\
\text { payable } \\
\text { contractors, } \\
\text { employees, all types } \\
\text { of budgets, social } \\
\text { funds). }\end{array}$ & $\begin{array}{l}\text { Simultaneously } \\
\text { reduce the asset and } \\
\text { liability of the } \\
\text { balance sheet and, } \\
\text { consequently, the } \\
\text { balance sheet total } \\
\text { for the amount of } \\
\text { each economic } \\
\text { operation }\end{array}$ \\
\hline
\end{tabular}

Depending on the complexity of the product, determined by the required number of components and the actions to obtain them, the value chain of the product displays a highly branched graph, each arc of which defines either the main or logistic operation. And the graph itself, representing the value chain of a product, reflects the process of interaction between the participants in the creation of this product. Essentially, this graph reflects the logistics of supply from one performer to another.

Hence, the economic security of the enterprise directly depends on the effective management of logistics processes, both in the external and internal environment of the enterprise.

\section{MATERIALS AND MethodS}

Consequently, the economic security of the enterprise is 
determined by the timely fulfillment of mutual obligations, both by the enterprise and its owner, staff, partners, customers and the state (Fig. 1). As a consequence, the economic security of the enterprise is realized through the timely receipt of income to the owner, staff, partners and the state, as well as products to buyers.

If we consider that the central task of ensuring the economic security of an enterprise is to generate sufficient income for its owner, then it becomes obvious that the mission of the enterprise is formulated. From this point of view, the mission determines the list of products manufactured by the enterprise, as well as the volume of its output, price and quality parameters that allow to sell these products on the market. And the criterion of selection of operations from the chain of added each product is minimization of expenses of the enterprise. Therefore, it is possible to assume that at inclusion of operations of a chain of the added cost of a product in structure of business processes the received economy and makes the profit of the owner of the enterprise. And the rest of the income can remain unchanged, as the state can change nothing for such participants as "personnel", "buyers", "partners" (suppliers), replacing market relations with administrative ones. However, this provision is maintained only if the scale of production remains unchanged.

If the scale of production increases, both the amount of income and its distribution changes, first of all, in favor of the owner. Otherwise, the owner will have no interest in investing the activity of the enterprise and in increasing the volume of output.

The necessary condition for ensuring the economic security of the enterprise is the integrity and safety of its property, which is the responsibility of the personnel in general, and the responsible persons, accounting department, security department in particular. Possibilities of disposing of the property of the enterprise are legislatively defined and for the owner.

The sufficient condition of maintenance of economic safety of the enterprise is an effective use of its property, both in strategic, and in tactical aspect.

If the safety of the property is ensured by law, the efficiency of its use entirely falls on the shoulders of management, and the state can only create conditions for the promotion of creation, development and effective functioning, carrying out appropriate tax, credit and economic policy.

Among the main prerogatives of the company's management is the constant reproduction of key competencies and staff development, ensuring the availability of competitive advantages in the price, volume and quality of products. Due to competition, the enterprise becomes bankrupt after competitive advantages have expired. Personnel qualification is considered from the point of view of the degree of competence acquisition.

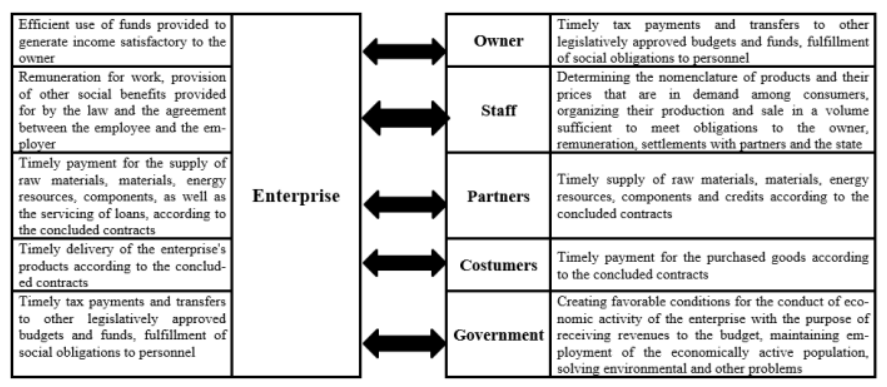

Fig. 1. Mutual obligations of the parties to the economic activity

Competences of management are shown not only in relation to the organization of production and sale of products, but also in the choice of partners, the reliability of which directly affects the efficiency and sustainability of economic activity and economic security of the enterprise.

Hence the problem of ensuring economic security of the enterprise by the management, which can be considered from various points of view (information, financial, product, technological, etc.). The criterion of management activity is efficiency, which is considered as the ratio of results to costs. Consequences of ineffective management decisions are realized as threats to information and economic security of the enterprise, which in case of untimely response to them constantly evolve. On the other hand, decisions made by management are based on forecasts of the state of external and internal environment of the enterprise and cannot be flawless. Therefore, the emergence of external and internal threats is inevitable, and in order to withstand them it is required to create the most effective and modern security measures using a comprehensive automatic active protection of enterprise resources from various attacks.

Such a system should be based on strategic and operational management [6]. Strategic management is directly related to the timely updating of products and the corresponding synchronous transformation of the enterprise architecture with the reproduction of the necessary key competences [1]. Operational management is carried out in the assumption of invariability of resources attracted for the implementation of the production program, formed under contracts of customers (buyers) [7].

Therefore, it is necessary to separate strategic and operational threats. If operational threats can arise relatively "suddenly", the strategic ones tend to be predictable and are the result of innovation, investment and dividend policy. Operational threats can and should be eliminated at the expense of the funds available to the enterprise, as well as resources attracted in the short term. Elimination of emerging strategic threats is associated with the clarification of the mission of the enterprise, its vision, as well as the updating of the entire pyramid of strategies, which ultimately leads to the renewal of the enterprise architecture [11].

The policy of economic security implemented by enterprises differs for different enterprises and industries. From this point of view, there is a need to classify enterprises, depending on their role in the economy. On the one hand, enterprises must meet the needs of the population living in the area in question. Such enterprises are backbone service 
enterprises and are focused on meeting the needs of the population permanently residing in a given territory. Hence, the interest in their activities, especially of local authorities. The legal framework of the territory should ensure the creation of comfortable conditions for the activities of local businesses, which in its mass is small and medium. Such enterprises compete with each other, and their price policy is determined by the ability to pay of the population of a settlement or region. But the represented group of enterprises cannot provide full employment of the economically active part of the population. Therefore, all levels of government are interested in attracting business to these areas to create new jobs [18].

The next group of enterprises is a systemically important one, as its products are mostly exported outside the populated area, region. Preferences of local legislation in this case are not enough. In this case, the creation of systemically important enterprises should already stimulate the legislative base of the state, which does not exclude the direct participation of local authorities in the attraction of business. In order to stimulate the creation of conditions for the effective functioning of systemically important enterprises, the legislation provides for a number of tax benefits, primarily in the interests of investors and owners, in order to increase the competitiveness of such enterprises. These enterprises, in fact, compete in the global market and are located in the territory that provides maximum income to owners. Income of such enterprises is directly related to the size of demand and price policy, which is determined by the needs and solvency of customers located outside the locality, region and even country [4]. The acuteness of competition also plays a significant role [3]. These enterprises compete in the global market, regardless of their strategic economic zones.

Thus, both system-servicing and system-forming enterprises strive to operate in an economically safe environment. But the owners of these enterprises assess economic security differently. Moreover, the authorities can interfere in the activities of these enterprises with different goals [9]. If the interference in the activities of backbone enterprises is carried out, as a rule, to protect the interests of consumers, then the systemically important enterprises are characterized by the protection of their interests, carried out to increase their competitiveness. To these ends, health care, education and social systems are aimed at maintaining a calm social environment and reproduction of competent and qualified labor force. It can be considered that the fundamental purpose of creating a comfortable environment for enterprises and their owners is not only to increase their income, but also to improve the living standards of the population, which increases the capacity of the market for all enterprises, regardless of their sphere of activity, thereby ensuring the growth of welfare of the same owners [19].

Systemically important enterprises are characterized by the scale of production and often operate in the global market. All enterprises, regardless of the category, associate the efficiency of their activities with solvent demand and the possibility of expanding or curtailing the scale of production of goods or services. International statistics are used to compare the performance of enterprises.
While competition between system providers can be controlled and regulated by the government, there are no constraints in the global market. Therefore, for the purpose of self-preservation, business owners turn to Governments and international organizations to unambiguously determine the state of the economy and social processes, as well as to regulate economic activity in order to overcome emerging conflicts that are destructive in nature. The government comes to the aid of, first of all, the owners of systemically important enterprises. As a rule, systemically important enterprises produce capital-intensive products, while system-servicing enterprises produce labor-intensive products. Therefore, the fiscal system is organized in such a way that system service enterprises have a relatively higher tax burden.

Each country has its own economic situation and each government pursues its own economic policy in order to find ways of development. Economic policy is a strategy and measures taken by the state in managing the economy to achieve its economic goals. The state strives to ensure full employment, price stability, economic growth and balance of payments, as well as efficient use of resources. In practice, due to the complexity of the relationship in the economy and its susceptibility to external influences, it is almost impossible to achieve all these goals simultaneously. Therefore, it is necessary to set priorities. Consequently, this process will inevitably be influenced by political considerations as well as economic ones.

The priority given to different economic goals will reflect the ideology of the government (which, at one extreme, is democratically elected, and at the other - dictatorship). The government, which adheres to a generally leftist ideology, has a positive attitude towards the expansion of state ownership of the means of production and increased interference in the economy in order to achieve its economic goals. While the government, which adheres to a generally right-wing ideology, has a positive attitude towards restricting state ownership and minimal interference in the economy, relying on market mechanisms. In practice, most countries have mixed economies in which both the public and private sectors operate.

Various measures are proposed by central or local authorities to support real private sector investment throughout the economy or in a particular area, which are seen as incentives for investment. Central government incentives can be implemented in the form of capital grants to cover the cost of equipment or in the form of profit tax breaks. Incentives to local governments usually consist in reducing or exempting individual local taxes and setting up local infrastructure for the convenience of potential investors. The main motive for providing support depends primarily on the goals pursued by the government [20]. Such an objective may be to reduce unemployment, in which case investments may help to address the problem through a multiplier effect. The aim may also be to provide additional assistance to specific development areas in addressing unemployment or urban reconstruction problems. 


\section{DISCUSSION}

Literary sources devoted to the problem of economic security of enterprises provide quite a large number of definitions of both the category of security and economic security of enterprises. As an example, let's consider the following definitions of economic security of an enterprise.

"Economic safety of the enterprise is a condition of the most effective use of corporate resources for prevention of threats and for maintenance of stable functioning of the enterprise now and in the future" [13]. This definition, touching upon the problem of effective use of property, defines the purpose of the enterprise as the fight against threats. Certainly, efficiency of use of corporate resources can characterize degree of economic safety of the enterprise.

"Economic security of the enterprise (firm) is such condition of the given economic subject at which vital components of structure and activity of the enterprise are characterized by high degree of protection against undesirable changes" [16]. This definition replaces "threats" with the concept of "undesirable changes" without defining what it is.

"Economic security of an enterprise is such a state of an economic entity, in which it, with the most effective use of corporate resources, achieves prevention, weakening or protection from existing hazards and threats or other unforeseen circumstances and mainly ensures the achievement of business objectives in conditions of competition and economic risk" [12].

This definition has already noted the goals of business and factors of its conduct - competition, economic risk. The criterion used - the efficiency of resource use - is based on the concept of threat, danger.

"Economic security of an industrial enterprise is a continuous process of providing at an industrial enterprise located in a certain external environment, stability of its functioning, financial equilibrium and regular profit making, as well as the possibility of fulfilling the set goals and objectives, its ability to further develop and improve at various stages of the life cycle of the enterprise and in the process of changing competitive market strategies" [15].

This definition sets out the tasks of management, including the provision of all possible aspects of the enterprise. The author considers the economic security of the enterprise as a process, not a state. This is a very important conclusion, as the economic security of the enterprise must exist continuously, at each point of the trajectory of its functioning. But it makes sense to note that the very economic security of the enterprise is a certain characteristic of the state of the enterprise, which is desirable to measure quantitatively either as a scalar or as a vector value. It is important that in this definition the author operates exclusively in economic categories.

"By economic security of entrepreneurial structure we will understand the protection of its vital interests from internal and external threats, i.e. protection of entrepreneurial structure, its personnel and intellectual potential, information, technologies, capital and profit, which is provided by a system of measures of special legal, economic, organizational, information-technical and social character" [14].

The author, recognizing the presence of the company's interests and structure, believes that the protection against external and internal threats, achieved by the system of measures, is the economic security of the enterprise. But protection is a tool to ensure economic security, and the interests of the enterprise are usually formulated by the management. The existing point of view focuses on continuously emerging threats, which are constantly leveled by managers. But most, if not all, of the threats are the result of previous management decisions. And all managerial decisions are to a greater or lesser degree risky. That is why it is inevitable that there will be negative consequences of managerial decisions taken and implemented.

Considering only threats, the role of enterprise managers is completely ignored by their actions generating these threats, sometimes even fatal for the enterprise. Therefore, when considering the economic security of the enterprise it is necessary to give priority attention to the activities of enterprise management, its ability to make such managerial decisions that minimize the negative consequences of their implementation.

When considering the management decisions of the management, it is necessary to highlight:

- strategic, which allow to realize effective and safe activity of the enterprise in the long term;

- Tactical, which are designed to implement strategic objectives in line with the current economic situation.

Strategic management decisions relate to the necessary changes in the architecture of the enterprise, based on the forced transformation of the product line according to the forecast. Adequate solutions for the transformation of enterprise architecture and their timely implementation and is designed to ensure the economic security of the enterprise.

\section{RESULTS}

Economic security of the enterprise is characterized by the ability to timely perform the enterprise on the one hand, and the owner, customers (buyers of products), personnel, partners and the state on the other.

The safety of property, its integrity and correctness of calculations on the economic operations, considered as the processes of interaction with the external environment (legal aspect) is considered as a necessary condition of ensuring economic security.

As a sufficient condition to ensure the economic security of the enterprise can be considered the effectiveness of the use of its property (economic aspect).

The importance of the legislative definition of economic security of the enterprise reflects the degree of convergence of interests of the state, population and business on the economy of the country. It is the activity of the enterprise that brings income to all the above parties and it is at the enterprise, as a source, that the primary distribution of income is carried out. Due to limited income and the desire of each party to increase its share, the company has always been a knot of contradictions in society. Being in the center of these contradictions, the enterprise not only brings income to all directly involved in its activities and meets the needs in goods, but also provides employment. Therefore, the creation of conditions for the safe operation of enterprises is the central link of the authorities at all levels, including the executive, 
legislative and judicial levels. The result of the activities of the authorities are legislative acts that create conditions for the activities of owners and entrepreneurs, who directly organize enterprises in order to generate income.

Thus, the definition of economic security of the enterprise and the conditions of its implementation lies at the heart of the ideology, which is implemented in practice.

\section{CONCLUSION}

The existing approach to ensuring the economic security of an enterprise as a science is to protect property. Not only does the security of the wallet not mean the security of its contents, it also does not ensure that it is filled. When it comes to property, we must not forget that it is only a means of generating revenue. The economic security of an enterprise is the security of the owner's income, although the security of the property as a means of generating income is a necessary condition, and the effective management of the property is a sufficient condition for generating income.

There are several points of view on the economic security of the enterprise, including the owner, the state, personnel who see the enterprise as a source of income, and buyers of products who satisfy their needs. At present, the prevailing view on the economic security of the enterprise is that of the enterprise:

- in the preservation of property, even from the owner;

- to eliminate uncertainty in the conduct of financial and business activities in order to maximize tax revenues.

This is clearly not enough to satisfy not only the appetite of the owner, but also to reflect the interests of buyers (customers), staff, partners and the state in the activities of the enterprise. Therefore, it is necessary to focus on property management, on those managerial decisions that ensure the efficiency of its use.

\section{REFERENCES}

[1] Ansoff, I. (2013). 'Strategic management. Translated from English', Ekonomi-ka Publishing House. Moscow: 285

[2] Davenport T. H. Business Innovation, Reengineering Work through Infor-mation Technology , Boston, Harvard Business School Press, 1993

[3] Deming W. E. Quality, productivity, and competitive position. - Cambridge, MA: Massachusetts Institute of Technology, Center for Advanced En-gineering Study, 1982

[4] 4. Felzensztein, C., Stringer, C., Benson-Rea, M., Freeman, S. (2014). 'Interna-tional marketing strategies in industrial clusters: Insights from the Southern Hemisphere', Journal of Business Research, 67(5): 837846

[5] Gereffi, G., Lee, J. (2016). 'Economic and social upgrading in global value chains and industrial clusters: Why governance matters', Journal of Business Ethics, 133(1): 25-38.

[6] Kotler, P., Berger, R., Bikhoff, N. (2012). 'Strategic Management by Ko-tler', Best practices and techniques $=$ The Quintessence of Strategic Manage-ment: What You Really Need to Know to Survive in Business.

[7] Mintzberg Henry The Structuring of Organizations: A Synthesis of the Re-search. Published by Lebanon, Indiana, U.S.A.: Prentice Hall (1979), p. 512

[8] Porter, Michael E. Competitive Advantage: Creating and Sustaining Superi-or Performance. - New York: The Free Press, 1985 (2nd ed. New York: Free Press, 1998. - 592 p.

[9] Porter M. E. The Competitive Advantage of Nations / M. E. Porter. New York: Free Press, 1990. - 875 p.
[10] Schwab Klaus The fourth industrial revolution. 2016 by World Economic Forum - All rights reserved. 172 pages

[11] Zhemchugov, A.M., Zhemchugov, M.K. (2011). 'Strategic vision and enterprise strategy', Problems of Economics and Management, 1 (1).

[12] Grunin O. A., Grunin S. O. Economic security of the organization. St. Petersburg: Peter, 2002, - $160 \mathrm{p}$.

[13] Fundamentals of economic security (State, region, enterprise, person) / Under edition of E.L.Oleinikova. M.: Intel-Syntez, 1997. - 138 p.

[14] Melamedov S. L. Formation of the strategy of economic security and entrepreneurial structures. PhD in Economics, St. Petersburg, 2002

[15] Polovnev K. S. Mechanism of ensuring economic security of the industrial enterprise $\mathrm{PhD}$, Yekaterinburg, 2002

[16] Business Strategy. Handbook / Under the editorship of G.B. Kleiner. MOSCOW: CONSECO, 1998. -288 p.

[17] Ilin, I., Kalinina, O., Iliashenko, O., Levina, A. Sustainable Urban Development as a Driver of Safety System Development of the Urban Underground (2016) Procedia Engineering, 165, pp. 1673-1682. DOI: 10.1016/j.proeng.2016.11.909

[18] Zaychenko, I., Borremans, A., \& Gutman, S. (2018). Analysis of administrative barriers in the industry of the high-rise construction in russian federation. Paper presented at the E3S Web of Conferences, , 33 doi:10.1051/e3sconf/20183303010

[19] Marchenko R.S. Improvement of the Quality of Calculations Using the Monte Carlo Simulation Method in the Evaluation of Mining Investment Projects / R.S. Marchenko, A.E. Cherepovitsyn // Proceedings of the 2017 International Conference \&quot;Quality Management, Transport and Information Security, Information Technologies\&quot; (IT\&amp;QM\&amp;IS) September, 24-30. - 2017. - C. 239-243.

[20] Levina, A.I., Dubgorn, A.S., Iliashenko, O.Y. Internet of things within the service architecture of intelligent transport systems (2018) Proceedings - 2017 European Conference on Electrical Engineering and Computer Science, EECS 2017, pp. 351-355. DOI: 10.1109/EECS.2017.72 